\title{
Cognitive impairment in COPD: a systematic review*
}

\author{
Comprometimento cognitivo em pacientes \\ com DPOC: uma revisão sistemática
}

\author{
Irene Torres-Sánchez, Elisabeth Rodríguez-Alzueta, Irene Cabrera-Martos, \\ lsabel López-Torres, Maria Paz Moreno-Ramírez, Marie Carmen Valenza
}

\begin{abstract}
The objectives of this study were to characterize and clarify the relationships between the various cognitive domains affected in COPD patients and the disease itself, as well as to determine the prevalence of impairment in the various cognitive domains in such patients. To that end, we performed a systematic review using the following databases: PubMed, Scopus, and ScienceDirect. We included articles that provided information on cognitive impairment in COPD patients. The review of the findings of the articles showed a significant relationship between COPD and cognitive impairment. The most widely studied cognitive domains are memory and attention. Verbal memory and learning constitute the second most commonly impaired cognitive domain in patients with COPD. The prevalence of impairment in visuospatial memory and intermediate visual memory is $26.9 \%$ and $19.2 \%$, respectively. We found that cognitive impairment is associated with the profile of COPD severity and its comorbidities. The articles reviewed demonstrated that there is considerable impairment of the cognitive domains memory and attention in patients with COPD. Future studies should address impairments in different cognitive domains according to the disease stage in patients with COPD.
\end{abstract}

Keywords: Pulmonary disease, chronic obstructive; Mild cognitive impairment; Hypoxia, brain.

\section{Resumo}

Os objetivos deste estudo foram caracterizar e esclarecer as relações entre os vários domínios cognitivos afetados em pacientes com DPOC e a doença em si, assim como determinar a prevalência de comprometimentos cognitivos em tais pacientes. Para tanto, foi realizada uma revisão sistemática utilizando as seguintes bases de dados: PubMed, Scopus e ScienceDirect. Os artigos incluídos forneciam informações sobre os comprometimentos cognitivos em pacientes com DPOC. A revisão dos achados de tais artigos mostrou uma relação significativa entre DPOC e comprometimento cognitivo. Os domínios cognitivos mais estudados são a memória e a atenção. Memória verbal e aprendizagem constituem o segundo domínio cognitivo mais comumente prejudicado em pacientes com DPOC. A prevalência de comprometimento da memória visuoespacial e da memória visual intermediária é $26,9 \%$ e $19.2 \%$, respectivamente. Observamos que o comprometimento cognitivo está associado ao perfil de gravidade da DPOC e suas comorbidades. A revisão dos artigos demonstrou que há um comprometimento considerável dos domínios memória e atenção em pacientes com DPOC. Investigações futuras devem abordar os comprometimentos em diferentes domínios cognitivos em conformidade com o estágio da doença em pacientes com DPOC.

Descritores: Doença pulmonar obstrutiva crônica; Comprometimento cognitivo leve; Hipóxia encefálica.

\section{Introduction}

The hallmark of COPD is chronic airflow obstruction that has a systemic impact and a progressive evolution. ${ }^{(1)}$ It is an important health problem that is estimated to become the fifth leading cause of disability and the third leading cause of death worldwide by $2020 .{ }^{(2)}$ The prevalence of COPD in the global population is close to one percent and increases with age. Among individuals 40 years of age or older in the city of São Paulo, Brazil, its prevalence ranges from 6 to $15.8 \% .^{(3)}$

The typical profile of patients with COPD includes multiple comorbidities, ${ }^{(4,5)}$ such as heart

*Study carried out in the Department of Physical Therapy, Health Sciences Faculty, University of Granada, Granada, Spain.

Correspondence to: Marie Carmen Valenza. Department of Physical Therapy, University of Granada, Av. de la llustración s/n, 18016, Granada, Spain.

Tel. 34958 248-035. Email: cvalenza@ugr.es

Financial support: This work was supported by the Professional Association Of Physiotherapists of Andalusia, Spain (Grant no. SG/0300/13C0) and by the Sociedad Española de Neumología y Cirugía Torácica/Fundación Española del Pulmón (SEPAR/Respira, Spanish Society of Pulmonology and Thoracic Surgery/Lung Foundation of Spain; Grant no. 061/2013).

Submitted: 16 September 2014. Accepted, after review: 2 February 2015. 


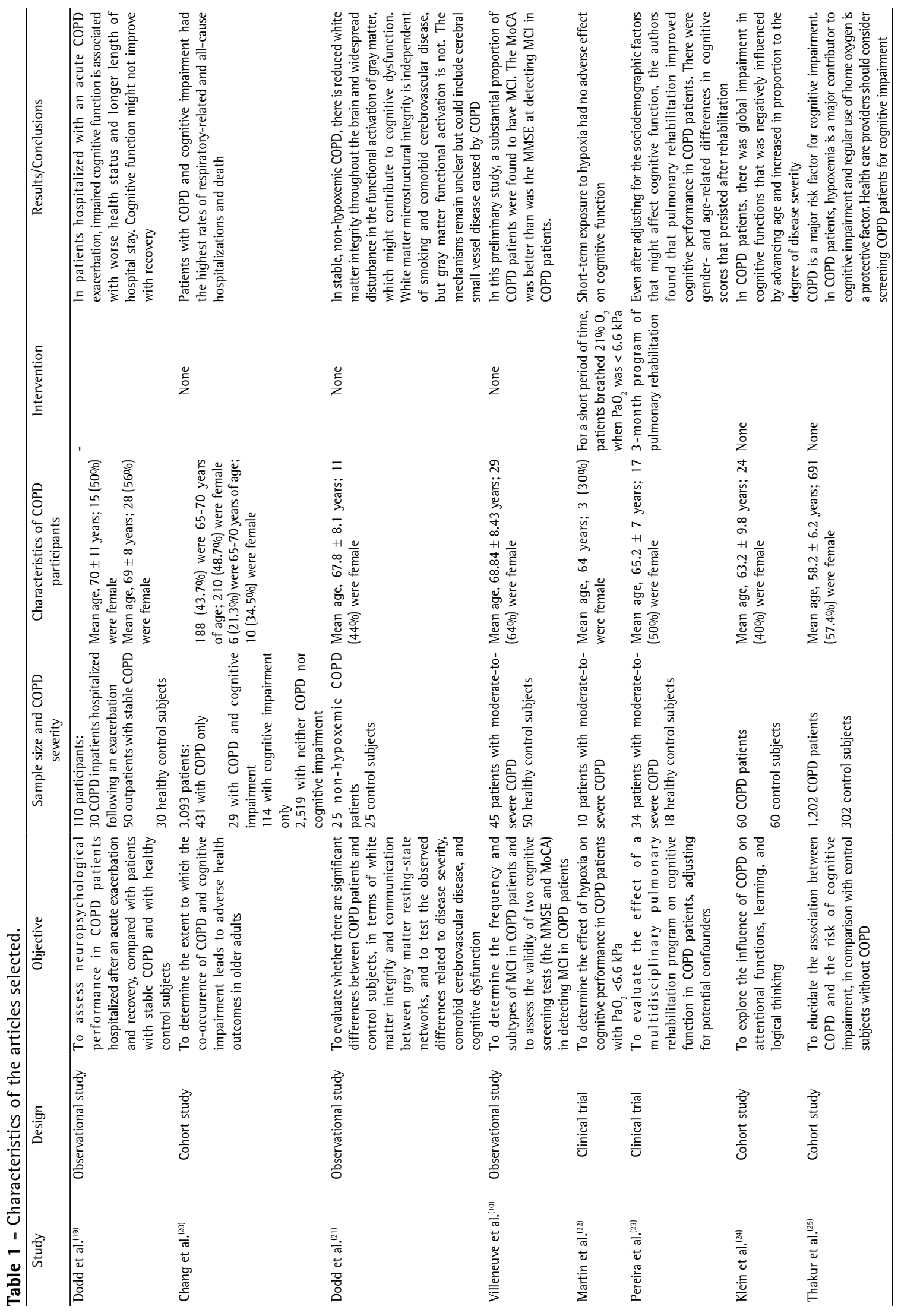




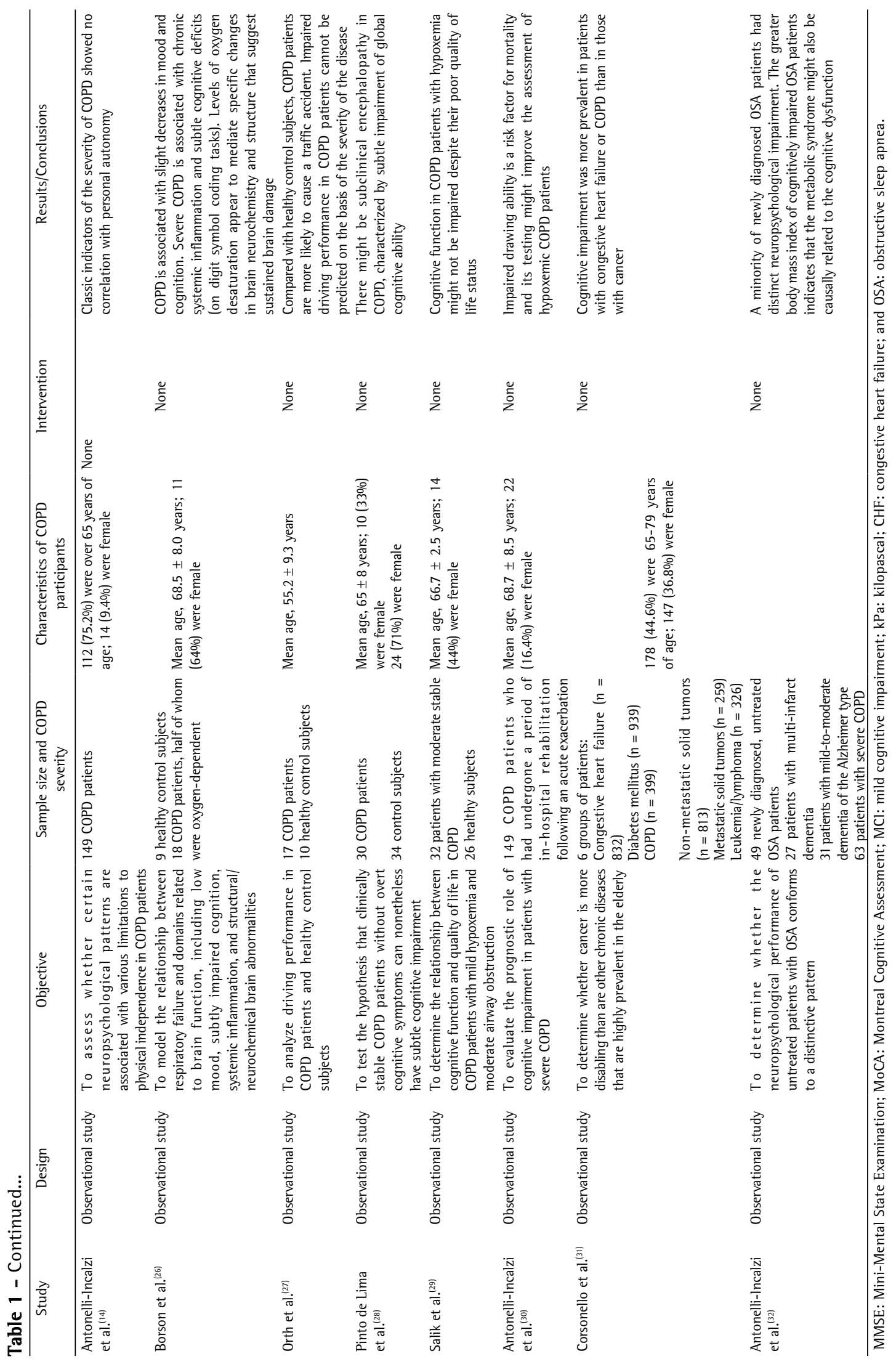


disease, ${ }^{(6)}$ osteoporosis, ${ }^{(7)}$ type 2 diabetes mellitus, ${ }^{(8)}$ lung cancer, ${ }^{(9)}$ and cognitive impairment. ${ }^{(10)}$ In recent years, the clinical relevance of cognitive impairment has risen, ${ }^{(11)}$ due to the increase in the prevalence of COPD and the growing interest in the aspects that determine functionality and treatment compliance ${ }^{(12,13)}$ among patients with the disease. ${ }^{(14)}$

Although COPD and cognitive impairment have been studied separately (as individual diseases), there is growing evidence of a relationship between the two. ${ }^{(11)}$ Hugg et al. ${ }^{(15)}$ analyzed cognitive impairment in patients with COPD and found that such patients had a greater risk of developing cognitive impairment than did patients without COPD. The hypoxemia seen in some patients with COPD seems to be a crucial factor for cognitive impairment, because it affects the oxygen-dependent enzymes that are important in the synthesis of neurotransmitters such as acetylcholine. ${ }^{(16)}$ Various studies have shown that cognitive impairment has a prevalence of $77 \%$ in patients with COPD and hypoxemia. ${ }^{(17)}$

The main hypotheses of this review were that there is a relationship between the various cognitive domains affected in COPD patients and the disease itself, and that the prevalence of impairment varies among the different cognitive domains. The objective of this review was two-fold: to characterize and clarify the relationship between the various cognitive domains affected in COPD patients and the disease itself; and to determine the prevalence of impairment in the various cognitive domains in such patients.

\section{Methods}

In this review of the literature, we adopted the classification of cognitive domains devised by Lezak. ${ }^{(18)}$ According to that author, who is the current reference in neuropsychological assessment, the cognitive domains correspond to five key areas: perception; attention; memory and learning; executive function; and language. We adopted a systematic approach using the following search strings (comprising terms related to COPD and to the Lezak classification of cognitive domains): "cognitive impairment" AND "COPD”; "cognitive decline" AND "COPD"; "cognitive dysfunction" AND "COPD"; "hypoxia" AND "cognitive impairment" AND "pulmonary disease"; "cognitive impairment" AND "hypercapnia" AND "pulmonary disease"; "cognitive attention" AND "COPD"; "memory and learning" AND "COPD”; "memory learning” AND "COPD" AND "cognitive"; "perceptive function" AND "COPD"; "verbal language" AND "COPD"; and "executive functions" AND "COPD".

We systematically searched the following databases: PubMed, Scopus, and ScienceDirect. Searches were limited to studies in humans published in the last ten years in order to focus on the recent interest and scientific evidence in this area. The inclusion criteria were being a clinical trial, epidemiological study, observational study, cohort study, or case-control study; and providing information on the subject at hand (i.e., cognitive impairment in COPD patients). We excluded articles that dealt with subjects unrelated to this topic, those that were not available in full text, and those that were review articles or simple case reports, as well as those published in languages other than English, Spanish, or French. The article selection process is depicted as a flowchart in Figure 1.

\section{Results}

The search yielded 478 articles. After the abstracts had been reviewed, only 16 articles were selected for inclusion in the review. The characteristics of the selected articles are shown in Table 1. Our review of those studies revealed a significant relationship between COPD and cognitive impairment. It is important to point out that there is as yet no consensus regarding the definition of cognitive impairment in patients with COPD. Different operational definitions of such impairment among the studies reviewed made it difficult to evaluate that aspect across those studies.

Given the multiple classifications of cognitive domains and the complexity of the assessment tools available, we chose the classification proposed by Lezak, ${ }^{(18)}$ which is one of the most complete and comprehensive such classifications devised to date. Table 2 shows the various tests used and the cognitive domains assessed in the selected articles.

Of the 16 studies selected, 14 were descriptive studies and two were experimental studies. Of the 14 descriptive studies, 11 were observational studies and three were cross-sectional studies.

\section{Discussion}

Various controlled studies have investigated the prevalence of cognitive impairment in 


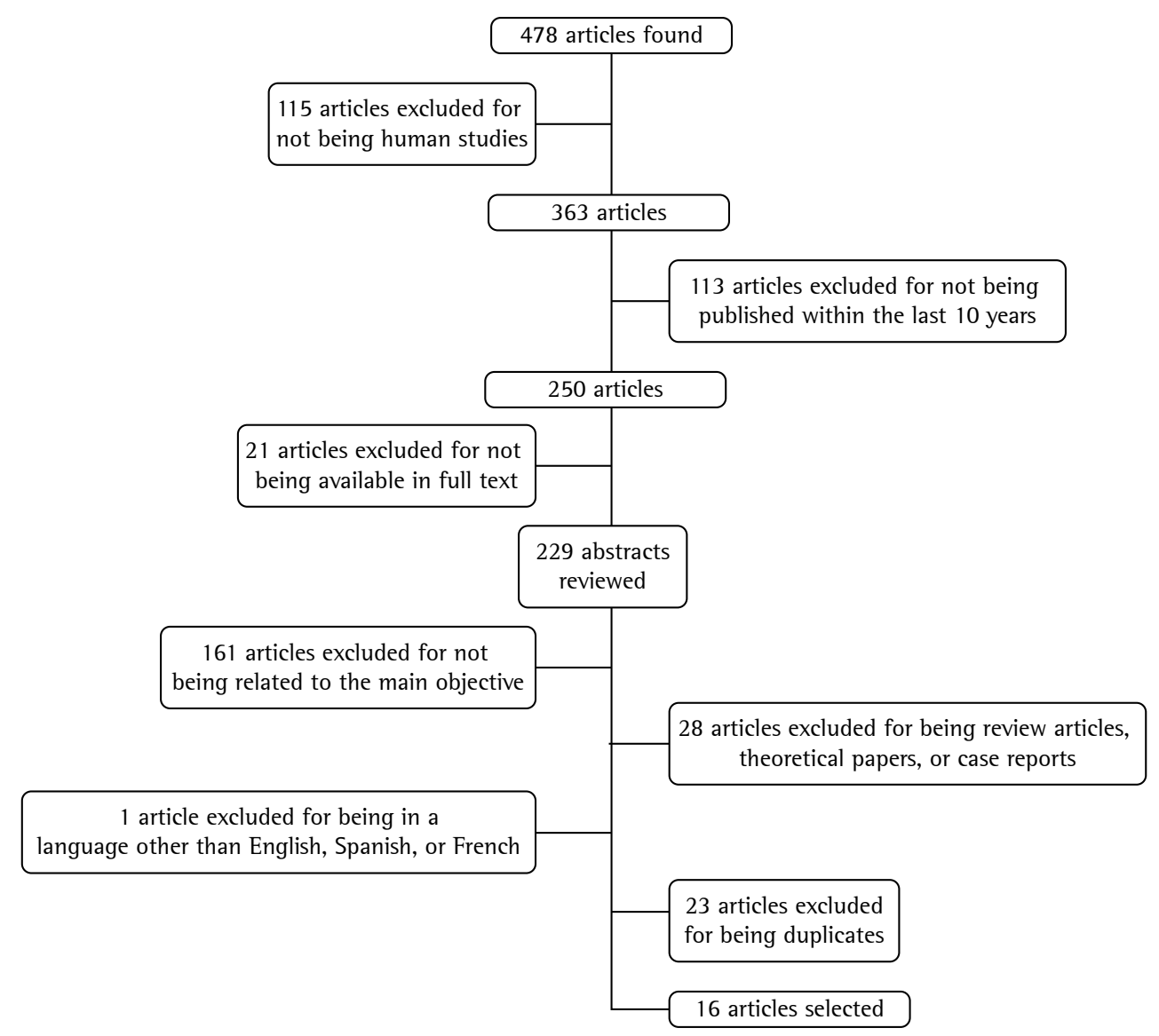

Figure 1 - Selection of the articles analyzed in this review.

COPD, ${ }^{(21,25,28)}$ showing that prevalence to be higher in COPD patients than in healthy control subjects. ${ }^{(10,31)}$ According to such studies, mild cognitive impairment is present in 36\% of COPD patients and in $12 \%$ of subjects without COPD. In a study conducted by Antonelli-Incalzi et al., ${ }^{(30)}$ the prevalence of cognitive impairment and severe cognitive impairment in COPD patients was found to be $32.8 \%$ and $10.4 \%$, respectively.

The prevalence of cognitive impairment in patients with COPD was found to be associated with the severity of the disease, ${ }^{(20,25)}$ being 3.9\% among patients with mild COPD, 5.7\% among patients with moderate COPD, and 7.7\% among patients with severe COPD. In fact, a relationship has been found between the Mini-Mental State Examination score and the severity of COPD $(r=-0.49, p<0.001) .{ }^{(28)}$ However, the study conducted by Salik et al. ${ }^{(29)}$ showed that cognitive function in COPD patients with mild hypoxemia was similar to that observed for healthy subjects. According to those authors, cognitive function is affected by hypoxemia only when the latter is severe. In addition, Grant et al. ${ }^{(17)}$ reported a $77 \%$ prevalence of cognitive impairment in patients with hypoxemic COPD. The reasons for this variation across studies include differences in the degree of COPD severity and in the age of the patients included in the studies, as well as the use of different diagnostic criteria for cognitive dysfunction and different cognitive tests.

The studies included in our review had large sample sizes and included a great variety of patients, which reduces any bias in prevalence rates. It is known that COPD is associated with an increased risk of impaired cognitive function, ${ }^{(26)}$ even when the data are adjusted for age, gender, smoking history, and level of education. ${ }^{(19,25)}$ Villeneuve et al. ${ }^{(10)}$ reported that level of education was the only variable for which there were significant differences among COPD patients with mild cognitive impairment, COPD patients without cognitive impairment, and healthy control subjects. ${ }^{(10)}$ The authors ruled out strokes and 
other cardiovascular diseases (all of which are common among COPD patients) as risk factors. Low peripheral oxygen saturation $(\leq 88 \%)$ has been strongly associated with a risk of cognitive impairment in patients with COPD, and the use of home oxygen therapy has been associated with a reduction in that risk. ${ }^{(25)}$ Numerous studies have explored the relationship between COPD and cognitive impairment. While some studies have addressed this issue globally using screening tests, others have focused on the assessment of specific cognitive domains. ${ }^{(10,24,27)}$

Perception is a series of processes and activities through which we extract information about our environment, the actions we perform within it, and our own state. Perceiving the environment requires a proper combination of attention and perception. Therefore, even though attention and perception are considered separate areas in the Lezak classification, they are often assessed together. Hypothesizing that automobile accidents would be more common among drivers with COPD than among those without, Orth et al. ${ }^{(27)}$ compared COPD patients with healthy control subjects, in terms of complex attentional and perceptual functions. The authors found that, in simulated driving situations, COPD patients showed lower concentration values and had a significantly higher number of accidents than did the healthy control subjects. ${ }^{(27)}$ According to various studies, ${ }^{(10,24)}$ attentional and executive functions are commonly impaired in the main subtype of mild cognitive impairment found in patients with COPD.

Learning implies acquiring information and therefore changes the state of memory. Verbal memory is one of the cognitive domains that are most frequently impaired in patients with COPD. ${ }^{(31)}$ According to Villeneuve et al., ${ }^{(10)}$ verbal memory and learning is the second most commonly impaired cognitive domain in patients with COPD. In such patients, the prevalence of impairment in visuospatial memory and intermediate visual memory is $26.9 \%$ and $19.2 \%$, respectively. ${ }^{(14)}$ In patients with COPD and sleep apnea, verbal memory and visual memory are the most commonly affected cognitive domains, ${ }^{(30)}$ although processing speed, working memory, and executive function are also affected $(p=0.01, p=0.02$, and $p \leq$ 0.001 , respectively). ${ }^{(21)}$

The term "executive functions", coined by Lezak, refers to skills involved in formulating goals, planning their achievement, and effectively performing behaviors. ${ }^{(18)}$ The assessment of executive functions in patients with COPD has shown that such patients tend to have slower processing speeds. ${ }^{(19)}$ Twenty percent of patients with exacerbated COPD exhibit a loss in processing speed that is significant enough to be considered pathological. Slower processing speed has been related to the duration of hospital stay, quality of life measured with the Saint George's Respiratory Questionnaire, and the number of COPD exacerbations. ${ }^{(19)}$

The ability to understand and communicate is determined by language. This mental process enables structured thinking, allowing an individual to make connections between ideas and mental representations. There have been studies evaluating cognitive function in a number of diseases, ${ }^{(30)}$ including sleep apnea and COPD. Patients with COPD and sleep apnea have been found to perform more poorly on tests of verbal fluency and deductive thinking than do COPD patients without sleep apnea. There are data indicating that only 3\% of COPD patients have a completely normal cognitive profile. ${ }^{(19)}$

We made cognitive impairment the focus of the present review because it is a common comorbidity in patients with COPD. The strength of our review is that it explored the relationship between COPD and cognitive impairment in the various cognitive domains over the last ten years, during which time a number of relevant clinical studies on this subject have been conducted. In addition, the studies included had large sample sizes. There have been a number of reviews of cognitive impairment in elderly people and COPD patients. ${ }^{(33-36)}$ The review conducted by Schillerstrom et al. ${ }^{(33)}$ addressed the impact of medical illness on executive function. In another review, Dodd et al. ${ }^{(11)}$ explored the mechanisms that cause injury and dysfunction in the brain, discussing the methods used in order to evaluate cognition, gathering evidence on the nature and level of cognitive impairment in COPD. Another recent review, conducted by Schou et al., ${ }^{(37)}$ investigated the occurrence and severity of cognitive dysfunction in COPD patients, exploring the relationship between the severity of COPD and the level of cognitive function. In our review, we included nine new studies about COPD and cognitive impairment, conducted between 2009 and 2013, which were excluded from the review 
Table 2 - Tests or batteries of tests used in the assessment of the cognitive domains under study in the articles selected.

\begin{tabular}{|c|c|c|c|c|c|c|c|}
\hline \multirow{2}{*}{$\begin{array}{l}\text { Neuropsychological assessment } \\
\text { instrument or function assessed }\end{array}$} & \multicolumn{7}{|c|}{ Cognitive domain } \\
\hline & Perception & Attention & $\begin{array}{l}\text { Memory } \\
\text { and } \\
\text { learning }\end{array}$ & $\begin{array}{c}\text { Abstract } \\
\text { thinking and } \\
\text { executive } \\
\text { function }\end{array}$ & Language & Intelligence & $\begin{array}{c}\text { General } \\
\text { (global } \\
\text { screening) }\end{array}$ \\
\hline Wechsler Test of Adult Reading ${ }^{(19,22)}$ & & & & & & $x$ & \\
\hline $\begin{array}{l}\text { Mini-Mental State } \\
\text { Examination }^{(10,19-21,25,28-30)}\end{array}$ & & & & & & & $x$ \\
\hline $\begin{array}{l}\text { Rey Complex Figure Test-Copy and Rey } \\
\text { Complex Figure Test-Recall }{ }^{(19,21,22)}\end{array}$ & & & $x$ & & & & \\
\hline Wechsler Memory Scale-1II UK Word Lists ${ }^{(19)}$ & & & $x$ & & & & \\
\hline Delis-Kaplan Verbal Fluency test ${ }^{(19)}$ & & & & & $\mathrm{x}$ & & \\
\hline Delis-Kaplan Trail Making Test ${ }^{(10,19,22)}$ & & & & $\mathrm{x}$ & & & \\
\hline $\begin{array}{l}\text { Wechsler Adult Intelligence Scale-111 UK } \\
\text { Letter-Number Sequencing } \\
(19,21)\end{array}$ & & & & $x$ & & & \\
\hline $\begin{array}{l}\text { Wechsler Memory Scale-111 UK Spatial } \\
\text { Span }^{(19,23)}\end{array}$ & & & & $x$ & & & \\
\hline $\begin{array}{l}\text { Wechsler Adult Intelligence Scale-111 } \\
\text { Digit Symbol(19,26) }\end{array}$ & & & & $x$ & & & \\
\hline $\begin{array}{l}\text { Wechsler Adult Intelligence Scale-111 } \\
\text { Symbol Search } \\
(19,21)\end{array}$ & & & & $x$ & & & \\
\hline Montreal Cognitive Assessment ${ }^{(10)}$ & & & & & & & $x$ \\
\hline $\begin{array}{l}\text { Digit Span Test (Wechsler Adult } \\
\text { Intelligence Scale-111) }\end{array}$ & & $x$ & & $x$ & & & \\
\hline $\begin{array}{l}\text { Digit Symbol coding test (Wechsler Adult } \\
\text { Intelligence Scale-111) })^{(10)}\end{array}$ & & $\mathrm{x}$ & & $x$ & & & \\
\hline Semantic Verbal Fluency'(10) & & $x$ & & $x$ & & & \\
\hline Letter verbal fluency (P, F and L) ${ }^{(10)}$ & & $\mathrm{x}$ & & $x$ & & & \\
\hline Rey Auditory Verbal Learning Test ${ }^{(10,23)}$ & & & $x$ & & & & \\
\hline Block Design $^{(10)}$ & $x$ & & & & & & \\
\hline Bells Test ${ }^{(10)}$ & $x$ & & & & & & \\
\hline $\begin{array}{l}\text { Word Lists Learning, Delayed Recall, and } \\
\text { Delayed Recognition (Wechsler Memory } \\
\text { Scale-111) }\end{array}$ & & & $x$ & & & & \\
\hline $\begin{array}{l}\text { Verbal Fluency-FAS task (Delis-Kaplan } \\
\text { Executive Function System) }\end{array}$ & & & & $x$ & & & \\
\hline Stroop Color-Word Test ${ }^{(10,23)}$ & & & & $x$ & & & \\
\hline Attention Network Test ${ }^{(24)}$ & & $x$ & & $x$ & & & \\
\hline Standard Progressive Matrices ${ }^{(24)}$ & & & & & & & \\
\hline $\begin{array}{l}\text { Verbal and Nonverbal Learning Test (part } \\
\text { of the Vienna Test System) }{ }^{(24)}\end{array}$ & & & $x$ & & & & \\
\hline Raven's Colored Progressive Matrices ${ }^{(14)}$ & $x$ & & & & & & \\
\hline Phonemic verbal fluency test ${ }^{(14)}$ & & & & & $x$ & & \\
\hline $\begin{array}{l}\text { Corsi Block-Tapping task (visuospatial } \\
\text { span) }{ }^{(14)}\end{array}$ & $x$ & & $x$ & & & & \\
\hline Verbal word $\operatorname{span}^{(14)}$ & & $\mathrm{x}$ & $x$ & & & & \\
\hline Rey Auditory 15 -Word Learning test ${ }^{(14)}$ & & & $x$ & & & & \\
\hline Albert's test (visual exploration) ${ }^{(14)}$ & $x$ & & & & & & \\
\hline $\begin{array}{l}\text { Copying geometrical drawings with or } \\
\text { without landmarks }{ }^{(14)}\end{array}$ & $x$ & & & & & & \\
\hline Immediate Visual Memory Test ${ }^{(14)}$ & & & $x$ & & & & \\
\hline Sentence construction ${ }^{(14)}$ & & & & & $x$ & & \\
\hline $\begin{array}{l}\text { The Computer-Aided Risk Simulator } \\
\text { (driving simulator test) }^{(27)}\end{array}$ & $x$ & $x$ & & & & & \\
\hline Dementia Rating Scale-2(26) & & & & & & & $x$ \\
\hline Wide Range Achievement Test- $3^{(26)}$ & & & & & & $x$ & \\
\hline $\begin{array}{l}\text { Logical memory subtest of the Wechsler } \\
\text { Memory Scale-111(26) }\end{array}$ & & & $x$ & & & & \\
\hline Mental Deterioration Battery ${ }^{(30)}$ & & & & & & & $x$ \\
\hline $\begin{array}{l}\text { 10-item Hodkinson Abbreviated Mental } \\
\text { Test }^{(31)}\end{array}$ & & & & & & & $x$ \\
\hline
\end{tabular}


conducted by Schou et al., ${ }^{(37)}$ because they were not published within the date range set for the search of the literature in the latter.

One of the limitations of the present review is the great variety of outcome measures evaluated. However, our review of the literature clearly showed the existence of a relationship between COPD and cognitive impairment. That relationship appears to be determined by the severity of COPD and by its comorbidities.

The most widely studied cognitive domains are memory and attention, both of which have been explored with specific assessment tools and found to be considerably impaired in patients with COPD. Evidence suggests that a structured assessment of cognitive function should be a routine component of the evaluation of COPD patients. Future studies should explore impairment in the various cognitive domains in COPD patients at different stages of the disease.

\section{References}

1. de Batlle J, Romieu I, Antó JM, Mendez M, Rodríguez E, Balcells E, et al. Dietary habits of firstly admitted Spanish COPD patients. Respir Med. 2009;103(12):1904-10. http://dx.doi.org/10.1016/j.rmed.2009.06.001

2. Jemal A, Ward E, Hao Y, Thun M. Trends in the leading causes of death in the United States, 1970-2002. JAMA. 2005;294(10):1255-9. http://dx.doi.org/10.1001/ jama.294.10.1255

3. Sociedade Brasileira de Pneumologia e Tisiologia. 11 Consenso Brasileiro sobre Doença Pulmonar Obstrutiva Crônica (DPOC). J Pneumol. 2004;30(Suppl 5):1-42.

4. de Oliveira JC, de Carvalho Aguiar 1, de Oliveira Beloto AC, Santos IR, Filho FS, Sampaio LM, et al. Clinical significance in COPD patients followed in a real practice. Multidiscip Respir Med. 2013;8(1):43. http://dx.doi. org/10.1186/2049-6958-8-43

5. Miravitlles M, Murio C, Tirado-Conde G, Levy G, Muellerova $\mathrm{H}$, Soriano JB, et al. Geographic differences in clinical characteristics and management of COPD: the EPOCA study. Int J Chron Obstruct Pulmon Dis. 2008;3(4):80314. http://dx.doi.org/10.2147/COPD.S4257

6. Sin DD, Lacy P, York E, Man SF. Effects of fluticasone on systemic markers of inflammation in chronic obstructive pulmonary disease. Am J Respir Crit Care Med. 2004;170(7):760-5. http://dx.doi.org/10.1164/ rccm.200404-5430C

7. Bolton CE, lonescu AA, Shiels KM, Pettit RJ, Edwards $\mathrm{PH}$, Stone MD, et al. Associated loss of fat-free mass and bone mineral density in chronic obstructive pulmonary disease. Am J Respir Crit Care Med. 2004;170(12):128693. http://dx.doi.org/10.1164/rccm.200406-7540C

8. Mannino DM, Thorn D, Swensen A, Holguin F. Prevalence and outcomes of diabetes, hypertension and cardiovascular disease in COPD. Eur Respir J. 2008;32(4):962-9. http:// dx.doi.org/10.1183/09031936.00012408

9. Wasswa-Kintu S, Gan WQ, Man SF, Pare PD, Sin DD. Relationship between reduced forced expiratory volume in one second and the risk of lung cancer: a systematic review and meta-analysis. Thorax. 2005;60(7):570-5. http://dx.doi.org/10.1136/thx.2004.037135

10. Villeneuve S, Pepin V, Rahayel S, Bertrand JA, de Lorimier $\mathrm{M}$, Rizk A, et al. Mild cognitive impairment in moderate to severe COPD: a preliminary study. Chest. 2012;142(6):151623. http://dx.doi.org/10.1378/chest.11-3035

11. Dodd JW, Getov SV, Jones PW. Cognitive function in COPD. Eur Respir J. 2010;35(4):913-22. http://dx.doi. org/10.1183/09031936.00125109

12. Allen SC, Jain M, Ragab S, Malik N. Acquisition and shortterm retention of inhaler techniques require intact executive function in elderly subjects. Age Ageing. 2003;32(3):299302. http://dx.doi.org/10.1093/ageing/32.3.299

13. Antonelli-Incalzi R, Gemma A, Marra C, Capparella O, Fuso L. Carbonin P. Verbal memory impairment in COPD: its mechanisms and clinical relevance. Chest. 1997;112(6):1506-13. http://dx.doi.org/10.1378/ chest.112.6.1506

14. Antonelli-Incalzi R, Corsonello A, Trojano L, Acanfora D, Spada A, lzzo 0, et al. Correlation between cognitive impairment and dependence in hypoxemic COPD. J Clin Exp Neuropsychol. 2008;30(2):141-50. http://dx.doi. org/10.1080/13803390701287390

15. Hung WW, Wisnivesky JP, Siu AL, Ross JS. Cognitive decline among patients with chronic obstructive pulmonary disease. Am J Respir Crit Care Med. 2009;180(2):134-7. http://dx.doi.org/10.1164/rccm.200902-02760C

16. Heaton RK, Grant I, McSweeny AJ, Adams KM, Petty TL. Psychologic effects of continuous and nocturnal oxygen therapy in hypoxemic chronic obstructive pulmonary disease. Arch Intern Med. 1983;143(10):1941-7. http:// dx.doi.org/10.1001/archinte.1983.00350100121023

17. Grant l, Heaton RK, McSweeny AJ, Adams KM, Timms RM. Neuropsychologic findings in hypoxemic chronic obstructive pulmonary disease. Arch Intern Med. 1982;142(8):1470-6. http://dx.doi.org/10.1001/archinte.1982.00340210062015

18. Lezak MD, Howieson DB, Loring DW. Neuropsychological assessment. 4th ed. New York: Oxford University Press; 2004.

19. Dodd JW, Charlton RA, van den Broek MD, Jones PW. Cognitive dysfunction in patients hospitalized with acute exacerbation of COPD. Chest. 2013;144(1):11927. http://dx.doi.org/10.1378/chest.12-2099

20. Chang SS, Chen S, McAvay GJ, Tinetti ME. Effect of coexisting chronic obstructive pulmonary disease and cognitive impairment on health outcomes in older adults. J Am Geriatr Soc. 2012;60(10):1839-46. http://dx.doi. org/10.1111/j.1532-5415.2012.04171.x

21. Dodd JW, Chung AW, van den Broek MD, Barrick TR, Charlton RA, Jones PW. Brain structure and function in chronic obstructive pulmonary disease: a multimodal cranial magnetic resonance imaging study. Am J Respir Crit Care Med. 2012;186(3):240-5. http://dx.doi.org/10.1164/ rccm.201202-03550C

22. Martin SE, Bradley JM, Buick JB, Crossan A, Elborn JS. The effect of hypoxia on cognitive performance in patients with chronic obstructive pulmonary disease. Respir Physiol Neurobiol. 2011;177(1):36-40. http:// dx.doi.org/10.1016/j.resp.2011.03.007

23. Pereira ED, Viana CS, Taunay TC, Sales PU, Lima JW, Holanda MA. Improvement of cognitive function after a three-month pulmonary rehabilitation program for COPD patients. Lung. 2011;189(4):279-85. http://dx.doi. org/10.1007/s00408-011-9303-6 
24. Klein M, Gauggel S, Sachs G, Pohl W. Impact of chronic obstructive pulmonary disease (COPD) on attention functions. Respir Med. 2010;104(1):52-60. http://dx.doi. org/10.1016/j.rmed.2009.08.008

25. Thakur N, Blanc PD, Julian LJ, Yelin EH, Katz PP, Sidney $\mathrm{S}$, et al. COPD and cognitive impairment: the role of hypoxemia and oxygen therapy. Int J Chron Obstruct Pulmon Dis. 2010;5:263-9. http://dx.doi.org/10.2147/ COPD.S10684

26. Borson S, Scanlan J, Friedman S, Zuhr E, Fields J, Aylward E, et al. Modeling the impact of COPD on the brain. Int J Chron Obstruct Pulmon Dis. 2008;3(3):429-34. http://dx.doi.org/10.2147/COPD.S2066

27. Orth M, Diekmann C, Suchan B, Duchna HW, Widdig W, Schultze-Werninghaus G, et al. Driving performance in patients with chronic obstructive pulmonary disease. J Physiol Pharmacol. 2008;59 Suppl 6:539-47.

28. Lima OM, Oliveira-Souza RD, Santos Oda R, Moraes PA, Sá LF, Nascimento OJ. Subclinical encephalopathy in chronic obstructive pulmonary disease. Arq Neuropsiquiatr. 2007;65(4B):1154-7. http://dx.doi.org/10.1590/ S0004-282X2007000700012

29. Salik Y, Ozalevli S, Cimrin AH. Cognitive function and its effects on the quality of life status in the patients with chronic obstructive pulmonary disease (COPD). Arch Gerontol Geriatr. 2007;45(3):273-80. http://dx.doi. org/10.1016/j.archger.2006.12.002

30. Antonelli-Incalzi R, Corsonello A, Pedone C, Trojano L, Acanfora D, Spada A, et al. Drawing impairment predicts mortality in severe COPD. Chest. 2006;130(6):1687-94. http://dx.doi.org/10.1378/chest.130.6.1687

31. Corsonello A, Pedone C, Carosella L, Corica F, Mezzei B, Incalzi RA. Health status in older hospitalized patients with cancer or non-neoplastic chronic diseases. BMC Geriatr. 2005;5:10. http://dx.doi.org/10.1186/1471-2318-5-10

32. Antonelli Incalzi R, Marra C, Salvigni BL, Petrone A, Gemma A, Selvaggio D, et al. Does cognitive dysfunction conform to a distinctive pattern in obstructive sleep apnea syndrome? J Sleep Res. 2004;13(1):79-86. http:// dx.doi.org/10.1111/j.1365-2869.2004.00389.x

33. Schillerstrom JE, Horton MS, Royall DR. The impact of medical illness on executive function. Psychosomatics. 2005;46(6):508-16. http://dx.doi.org/10.1176/appi. psy.46.6.508

34. Gasquoine PG. Cognitive impairment in common, noncentral nervous system medical conditions of adults and the elderly. J Clin Exp Neuropsychol. 2011;33(4):48696. http://dx.doi.org/10.1080/13803395.2010.536759

35. Landi F, Pistelli R, Abbatecola AM, Barillaro C, Brandi V, Lattanzio F. Common geriatric conditions and disabilities in older persons with chronic obstructive pulmonary disease. Curr Opin Pulm Med. 2011;17 Suppl 1:S29-34. http://dx.doi.org/10.1097/01.mcp.0000410745.75216.99

36. Corsonello A, Antonelli Incalzi R, Pistelli R, Pedone C, Bustacchini S, Lattanzio F. Comorbidities of chronic obstructive pulmonary disease. Curr Opin Pulm Med. 2011;17 Suppl 1:S21-8. http://dx.doi.org/10.1097/01. mcp.0000410744.75216.d0

37. Schou L, Østergaard B, Rasmussen LS, Rydahl-Hansen $\mathrm{S}$, Phanareth K. Cognitive dysfunction in patients with chronic obstructive pulmonary disease--a systematic review. Respir Med. 2012;106(8):1071-81. http://dx.doi. org/10.1016/j.rmed.2012.03.013

\section{About the authors}

\section{Irene Torres-Sánchez}

Researcher. Department of Physical Therapy, Health Sciences Faculty, University of Granada, Granada, Spain.

\section{Elisabeth Rodríguez-Alzueta}

Researcher. Department of Physical Therapy, Health Sciences Faculty, University of Granada, Granada, Spain.

\section{Irene Cabrera-Martos}

Researcher. Department of Physical Therapy, Health Sciences Faculty, University of Granada, Granada, Spain.

\section{Isabel López-Torres}

Researcher. Department of Physical Therapy, Health Sciences Faculty, University of Granada, Granada, Spain.

\section{Maria Paz Moreno-Ramírez}

Researcher. Department of Physical Therapy, Health Sciences Faculty, University of Granada, Granada, Spain.

\section{Marie Carmen Valenza}

Assistant Professor. Department of Physical Therapy, Health Sciences Faculty, University of Granada, Granada, Spain. 